\title{
Pazarlamada Marka Yönetimi Üzerine Literatür Taraması
}

\author{
Dr. Öğr. Üyesi Mualla AKÇADAĞ \\ Sivas Cumhuriyet Üniversitesi \\ makcadag@cumhuriyet.edu.tr \\ Orcid: 0000-0002-0785-3976
}

\section{Zerrin IȘIKSAL}

Sivas Cumhuriyet Üniversitesi

ztekeli@cumhuriyet.edu.tr

Orcid: 0000-0001-9364-5390

\section{ÖZ}

Küreselleşen pazarlardaki artan rekabet sonucu, ürün sayısı artmış ve bu ürünleri birbirinden ayırma ihtiyacı meydana gelmiştir. Bu nedenle işletmeler, hem ürünlerini diğer ürünlerden ayırt etme hem de tüketiciye vaat ettikleri belli bir kalite düzeyini koruma düşüncesi ile marka ve marka yönetimi faaliyetlerine önem vermektedir. Buradan hareketle bu çalışma ile son yıllarda globalleșen pazarlama ile artan rekabet koşullarında giderek önem kazanan marka ve marka yönetimi kavramlarını inceleyen makalelerin literatür taramasının yapılması amaçlanmıştır. Çalışmanın ana kütlesini 2013-2021 yılları arasında pazarlama konulu marka kavramının yer aldığı DergiPark'ta yayımlanan 61 makale oluşturmaktadır. Literatür incelemesi sonucunda çalışmaların en çok marka bağlılığı ve marka değeri üzerinde yoğunlaştığı anlaşılmaktadır. Marka performansı, marka tutumu, marka denkliği, marka aşk1, marka evangelizmi ve marka misillemesi konulu çalışmaların az sayıda olduğu tespit edilmiş ve çalışmalarda daha çok nicel araştırma yönteminin kullanıldığı belirlenmiştir. İncelemede literatür analizi şeklinde tek çalışmaya rastlanılmış ancak bu çalışmanın da sadece doktora tezlerini içerdiğinden literatürdeki boşluğun doldurulması istenmiştir.

Anahtar Kelimeler: Pazarlama, Marka, Marka Yönetimi, Literatür Taraması.

Atıf Bilgisi: Akçadağ, M., Işıksal, Z. (2021). Pazarlamada Marka Yönetimi Üzerine Literatür Taraması, Elektronik Cumhuriyet İletişim Dergisi,2021, 3(2), 87-112.

Sorumlu Yazar: Mualla AKÇADAĞ, makcadag@cumhuriyet.edu.tr 


\section{Literature Review on Brand Management in Marketing}

Assist. Prof. Mualla AKÇADA $\breve{G}$

Sivas Cumhuriyet University

makcadag@cumhuriyet.edu.tr

Orcid: 0000-0002-0785-3976
Zerrin IŞIKSAL

Sivas Cumhuriyet University

ztekeli@cumhuriyet.edu.tr

Orcid: 0000-0001-9364-5390

\section{ABSTRACT}

The number of items has increased as a result of greater rivalry in globalizing marketplaces, and the necessity to differentiate these products from one another has arisen. As a result, businesses place a premium on brand and brand management operations in order to distinguish their products from competitors while also ensuring that the consumer receives the quality they expect. From this perspective, the purpose of this study is to conduct a literature analysis of papers that examine the ideas of brand and brand management, which have become increasingly relevant in recent years as a result of increased rivalry international marketing. The study's primary body comprises of 61 articles published in DergiPark between 2013 and 2021 that cover the topic of brand on marketing. According to the findings of the literature study, research mostly focus on brand loyalty and brand value. There are few research on brand performance, brand attitude, brand equity, brand love, and brand loyalty. There are few studies on brand performance, brand attitude, brand equity, brand love, brand evangelism, and brand retaliation, and more quantitative research methodologies are utilized in the studies, according to the findings. Only one literature analysis research was found in the review, but because it only comprised doctoral theses, it was requested to fill the gap in the literature.

Key Words: Marketing, Brand, Brand Management, Literature Review.

Citation: Akçadağ, M., Işıksal, Z. (2021). Literature Review on Brand Management in Marketing, Electronic Cumhuriyet Journal of Communication, 2021, 3(2), 87-112.

First Author: Mualla AKÇADAĞ, makcadag@cumhuriyet.edu.tr 


\section{GİRIŞ}

Küreselleşme, şirketlerin ülke sınırlarını aşarak uluslararası pazarlarda yer almasını sağlayan büyük bir değişimdir. Teknolojik ilerlemeler sayesinde küreselleşen dünyada işletmeler, uluslararası pazarlara açılma şansını yakalamışlardır. Böylece işletmeler uluslararası pazarlarda ürünlerini pazarlamanın yanı sıra hedef kitlelerine ulaşma firsatı yakalamışlardır. İşletmeler, pazarda birbirine benzer ürün ya da rakiplerin çok olması nedeniyle kendi işletme ve ürünlerini diğerlerinkinden ayırmak için pazarlama faaliyetleri gerçekleștirmektedirler. Bu noktada marka, hedef kitle ve ürünler arasındaki bağlantıyı sağlayan bir araç olarak ön plana çıkmaktadır. Marka küreselleşen pazar içinde rekabetin en önemli unsurlarından biri haline gelmiştir. Sürdürülebilir rekabette işletmeler için ürünlerini satışında ve tanıtımında bilinir bir marka olmak ve marka değerinin gereğini yapmak kaçınılmaz hale gelmiştir. Marka faaliyetlerini oluştururken sektörün sosyal, coğrafi ve kültürel özelliklerinin dikkate alınması müşteri sadakati ile ilişkili durumdadır (Nergiz ve Çetindağ, 2019, s.5).

Bu çalışma ile DergiPark’ta belirtilen dönemlerde marka ve marka yönetimi alanında yayımlanan makaleler incelenerek çalışmaların sınıflandırılması, tablolaştırılması yapılmıştır. Ayrıca çalışmanın bulgular kısmında da literatürde marka ile ilgili çalışmaların en çok ve en az hangi konularda yoğunlaştığı, yayım dili, ulusal / uluslararası yayım türü, araştırma yöntemi, marka konusunun belirlenmesi ve yayım yılı gibi konularda da bilgi verilmektedir. Makalelerin detaylı incelemesi yapılarak marka konusunun araştırılma düzeyi derinleştirilmiştir.

\section{LITERATÜR TARAMASI}

Marka, hem gelişmiş hem de gelişmekte olan ülke firmalarının dünya pazarlarında yer sahibi olma ve ticaret hacmini arttırma bakımından kilit öneme sahiptir. Markanın hedef kitlesinin doğru belirlenmesi önem kazanmaktadır.

Marka ile ilgili çalışmalardan Baş ve Şahin (2013) yabancı isimli markaların, internet alışverişi yapan tüketicilerin satın alma davranış ve kararlarına etkisini araştırmayı amaçlamışlardır. Araştırma kapsamında hazırlanan anket Türkiye'de yaşayan internet kullanıcısı tüketicilere uygulanmıştır. Çalışmanın bulguları arasında yabancı isimli markaların fiyat ve kalite algıları üzerinde etkisi olduğu tespit edilmiştir.

Güzel (2014) ise çalışmasında seyahat ile ilgili bir sitede yer alan Antalya da faaliyet gösteren bir konaklama işletmesi üzerinde uygulama yapmıştır. Çalışmada işletmenin marka itibarını korunması açısından konaklama yeri ile ilgili web sitesinde yapılan 352 yorumla ilgili içerik analizi uygulanmıştır. Nicel araştırma sonucuna göre en çok rahatsızlık duyulan konu başlığının otelde konaklayan diğer misafirlere yönelik olduğu anlaşılmaktadır. Ayrıca otelin fiziksel çevresine yönelik, otel çalışanlarının eksikliklerine yönelik (yabancı dil bilmeme) rahatsızlıklar olduğu da belirtilmiştir. Yine çalışma so- 
nucunda otel hakkında olumsuz yorum yapan katılımcıların işletmeyi önermedikleri de vurgulanmıştır.

Karataş ve Bekçi (2017) çalışmalarında marka değeri belirlenirken hangi modellerin kullanılacağı sorusuna cevap verebilmeyi amaçlamışlardır. Çalışmada Türkiye'de finans sektöründe marka değerlemesi konusunda hangi analizin kullanılması gerektiğinin ortaya çıkarılabilmesi için AHP yöntemi kullanılmıştır. Analiz sonucunda finans sektörü için marka değerini ortaya çıkmasında en iyi modelin olamayacağı tespit edilmiştir.

Konuyla ilgili bir diğer çalışmada ise faaliyet gider türlerinin marka değeri üzerindeki etkisi belirlenmek istenmiştir. Bu amaçla Türkiye' deki ilk 100 finans bankası içinde yer alan 30 işletme ile uygulama yapılmıştır. Çalışmanın bulguları ise faaliyet gider türlerinin marka değeri üzerinde anlamlı bir etkisinin olduğudur (Koçan ve Gerekan, 2017).

Sarıçiçek vd. (2017) tarafından yapılan çalışmada ise retro pazarlama içerisinde yer alan marka imajı ve marka kimliği, tüketiciler açısından değerlendirilmiştir. Ayrıca nostalji ve marka ilişkisi de incelenmiştir. Çalışma Gaziantep Üniversitesi’nde görev yapan akademisyenlere anket uygulanarak gerçekleştirilmiştir. Çalışma sonucunda katılımcıların yaş faktörü ile algıladıkları marka imajı ve marka kimliği arasında ilişki tespit edilmiştir.

Bir diğer çalışmada ise bankacılık sektöründeki hizmet kalitesi algısının marka bağlılığı üzerine etkisi incelenmiştir. Araştırmanın uygulama bölümü için Mersin ili ilçelerinde bankacılık sektöründen hizmet alan 282 katılımcıya anket çalışması yapılmıştır. Analiz sonucunda elde edilen verilere göre hizmet kalitesinin marka bağl1lı̆̆ üzerinde olumlu bir etkisi olduğu anlaşılmıştır (Onan, 2017).

Aksoy (2018) tarafından yapılan çalışmada da markaların hedef kitleleri ile olan iletişim sürecinin çoklu sponsorluğa etkisi araştırılmıştır. Araştırmanın uygulama bölümü için bir Kart Teknoloji fuarına katılan katılımcılardan 210 kişiye anket uygulaması gerçekleştirilmiştir. Çoklu sponsorluk anlaşmalarında sponsorlu işletmelerde uyumun önemli olduğu ve marka imajına uygun konseptlerin faydalı olacağı tespit edilmiştir.

Konuyla ilgili bir diğer çalışmada ise hizmet sektöründe marka farkındalığının yabancı turistler açısından önemi araştırılmıştır. Çalışma sonucunda gelişim gösteren turizm işletmelerinin tüketici istek ve ihtiyaçlarına uygun faaliyetler geliştirmesinin marka kentlerinin oluşumunda etkili olduğu anlaşılmıştır (Çakır, 2018).

Tüketicilerin kişilik özellikleri ve marka sadakati arasında bir ilişkinin olup olmadığı tespit etmeyi amaçlayan çalışmada ise Kayseri'de öğrenim gören 582 üniversite öğrencisine anket yöntemi uygulanmıştır. Araştırma sonuçlarına göre marka sadakati ile uyumluluk arasında negatif yönlü bir ilişkinin olduğu saptanmış olup diğer bağımsız değişkenler ile marka sadakati arasında anlamlı bir ilişki olmadığı tespit edilmiştir (Yaprak ve Dursun, 2018). 
Akgün ve Tekin (2019) tarafından yapılan çalışmanın amacı ise; kurumsal itibar yönetimi uygulamalarının marka değeri üzerindeki etkisinin araştırılmasıdır. Çalışma Konya' da bulunan kamu ve özel hastanelerde çalışan toplam 242 doktor ve yöneticiye anket uygulanarak gerçekleşmiştir. Çalışma sonucunda özel hastanelerdeki katılımcıların kamu hastaneleri katılımcılarına göre kurumsal itibar yönetim ile ilgili faaliyetlerinin marka değeri üzerinde daha fazla etkili olduğu anlaşılmıştır.

Yapılan literatür taramasında göze çarpan bir diğer çalışmada ise tüketicilerin satın alma sürecinde markanın etkisi ölçülmüştür. Çalışmanın uygulama bölümü Adıyaman Üniversitesi öğrencilerinden 379' una anket uygulanarak gerçekleştirilmiştir. Analiz sonuçlarına göre diğer ürün kategorilerinin ortalama kullanım ve tercih oranının akıllı telefondan daha düşük olduğu ifade edilmiştir. Ayrıca diğer ürün kategorilerinde tercih edilen ve kullanılan markalar arasında oransal olarak önemli farklılıklar tespit edilmiştir. Satın almada marka ve fiyat etkisinin cinsiyet değişkenine göre anlamlı bir farklılık tespit edilmemiştir (Aslan ve Özbeyaz, 2019).

Atıgan (2019) ise çalışmasında bisküvi ve gofret sektöründe marka kişiliğinin satın alma davranışları üzerindeki etkisini incelemeyi amaçlamıştır. Çalışmanın uygulamaS1 Türkiye' deki bir devlet üniversitesindeki 2856 öğrenciye anket yöntemi kullanılarak oluşturulmuştur. Çalışmada öğrencilerin; marka tercihlerinde lider, başarılı, naziklik gibi özellikleri önemsedikleri belirtilmiştir.

Bir diğer çalışmada ise literatür taramasında çok az karşılaşılan marka nefreti üzerinde durulmuştur. Çalışma Hatay'ın Antakya İlçesinde akıllı cep telefonu markalarına karşı marka nefreti olan tüketicilere kartopu örneklem tekniği kullanılarak yapılmıştır. Çalışma sonucuna göre sembolik uyuşmazlık ve ideolojik uyumsuzluğun marka nefretini pozitif yönde ve anlamlı bir şekilde etkilediği ortaya çıkmıştır. Tüketicilerden marka nefreti olanların markadan kaçındığı ve olumsuz bir şekilde sözlü olarak diğer tüketicileri de etkilediği belirtilmiştir (Balıkçıŏlu ve Kıyak, 2019).

Çınar (2019) tarafından yapılan çalışmada ise dijital ortamda firma tarafından yapılan reklam harcamalarına yönelik algılamaların tüketici-marka bağlılığı boyutları üzerinde nasıl bir etkiye sahip olduğu araştırılmıştır. E-ticaret sitesinden alışveriş yapan toplam 319 kişiye anket uygulaması yapılmıştır. Çalışma sonucunda, dijital ortamda firma tarafından yapılan reklam harcamalarına yönelik algılamaların tüketicide markaya karşı duygusal, bilişsel ve davranışsal bağlılık düzeyini etkilediği tespit edilmiştir.

Spor sponsorluğu, marka imajı ve marka değeri arasındaki ilişkiyi ele alan çalışma ise marka değerlemeyi tüketici açısından incelemiştir. Çalışma İzmir ilinde yer alan devlet üniversitesinde lisans seviyesinde okuyan öğrencilere anket yöntemi uygulanarak yapılmıştır. Analiz sonuçlarına göre tüketicilerin sponsor marka olan işletmenin tutumlarının marka imajını etkilediği anlaşılmıştır (Deniz, 2019). 
Ercis vd. (2019) marka ile ilgili çalışmalarında benlik-marka bağının marka sadakati üzerindeki etkisinde, marka aşkı ve marka deneyiminin aracılık rolünün araştırılmasını amaçlamışlardır. Araştırma için Erzincan merkez ilçede de yaşayan cep telefonu kullanan üniversite öğrencilerine (384) anket uygulanarak gerçekleştirilmiştir. Araştırma sonucunda marka bağl1lığ yaratmada, benlik marka bağı, marka deneyimi ve marka aşkının etkili olduğu tespit edilmiştir.

Perakende sektöründeki markalı ürün tercihinin belirlenmesine yönelik olan çalışma 402 tüketiciye anket uygulanarak yapılmıştır. Sektördeki markaları değerlendiren katılımcı tüketicilerin mağaza ve fïyat değişkenlerinin, algılanan kalite ve risk faktörleri açısından olumsuz tutum sergiledikleri belirtilmiştir (Gürbüz ve Başkol, 2019).

Elagöz ve Yücekaya (2019) ise tüketici temelli marka değerinin ağızdan ağıza iletişim olayı üzerindeki etkisini ölçmektedir. Çalışma 2019 yılı Şubat-Nisan aylarını kapsayan dönemde Ankara, Tekirdağ ve Çanakkale illerinde 453 üniversite öğrencisine anket yöntemi uygulanarak oluşturulmuştur. Çalışma sonucuna göre ağızdan ağıza iletişimin, tüketici temelli marka değerini pozitif yönde etkilediği tespit edilmiştir.

Literatürde yer alan bir diğer çalışmada ise Demirağ ve Çavuşoğlu (2019) marka imajının tutumsal marka sadakatine olan etkisini belirlemektedir. Araştırma Bingöl'de bulunan tesislerde konaklayan 272 otel müşterisine anket uygulanarak gerçekleştirilmiştir. Analiz sonuçlarına göre tutumsal marka sadakatinin bazı boyutlarının (bilişsel, duygusal ve çabasal) marka imajı üzerinde etkisi olduğu tespit edilmiştir (Demirağ ve Çavuşoğlu, 2019).

Çiftçi vd. ise (2019) tüketicilerin online marka topluluklarına katılımları üzerindeki öz benlik uyumunun etkisini araştırmıştır. Çalışmada işletmelerin online marka toplulukları Instagram aracılığıyla 283 katılımcıya ulaşması ile uygulanan anket formları aracılığ 1 ile veriler elde edilmiştir. Çalışmanın sonucunda ise öz benlik uyumunun tüketicilerin online marka topluluklarına katılımları üzerinde etkili olduğu belirtilmiştir. Yine faydacı katılım, hazcı katılım, yardım alma ve marka tutkusunun kendi aralarında da neden-sonuç ilişkilerine sahip oldukları ve online marka topluluklarına katılım üzerinde aynı düzeyde etkili olmadıkları tespit edilmiştir.

Bir diğer çalışmada ise $\mathrm{X}$ ve $\mathrm{Y}$ kuşağı tüketicilerinin fast food ürünlerini tercih etmede marka algısı ve müşteri memnuniyeti arasındaki ilişki incelenmiştir. Çalışmanın uygulama bölümü Türkiye'deki bazı illerde bulunan X ve Y kuşağı tüketicilerinden 400 kişiye anket uygulanarak gerçekleştirilmiştir. Araştırma sonucunda katılımcıların marka algısı ve müşteri memnuniyetleri ile marka tercihleri arasında anlamlı bir ilişki olduğu belirlenmiştir (Kahraman ve Dağl1, 2019).

Marka menşei konusuna farklı bir açıdan yaklaşan Koçak ve Bayraktar ise (2019) marka kökenini tanıma seviyesini yardımsız olarak test edilmesini amaçlamışlardır. Bu 
çalışmada, Mısırlı 840 tüketiciye, Mısır'da faaliyet gösteren 12 Türk markasının menşelerini doğru tanıma testi yapılmıştır. Araştırma sonucunda katılımcılar tarafından Ülker, İstikbal ve Paşabahçe'nin en çok bilinen markalar olduğu sonucuna ulaşılmıştır (Koçak ve Bayraktar, 2019).

Tarama sırasında literatür analizi şeklindeki tek çalışma ise Öcel (2019) tarafından yapılmıştır. Çalışmada 1995 ve sonrasındaki 23 yıl arasında Türkiye'deki üniversitelerde marka alanında yazılmış doktora tezleri taranmıștır. Bu taramada marka konulu tezlerin yayımlanma yılı, yayım dili, tezlerde kullanılan araştırma yöntemleri gibi birçok konu başlığ 1 altında 221 doktora tezi bibliyometrik analiz yöntemi ile detaylı olarak incelenmiştir. Yapılan analiz sonucunda en çok marka değeri konusunun incelendiği ve nicel araştırma yönteminin en fazla tercih edildiği belirtilmiştir.

Alan yazında markaya ilişkin bir diğer çalışma ise Türkiye'de faaliyet gösteren seçilmiş şirketlerin ve bankaların mali performanslarını Brand Finance tarafından düzenli olarak açıklanan marka değerleri ile karşılaştırmayı amaçlamıştır. Çalışmada Brand Finance tarafindan yayınlanan listede 2007-2019 döneminde kesintisiz olarak yer alan halka açık 19 şirket ve 5 bankanın marka değerleme sonuçları esas alınmıştır. Araştırma sonuçlarına göre seçilen bankaların marka değerinin net faiz gelirlerinden düşük olduğu, seçilen şirketlerin marka değerlerinin ise net satışlarından düşük olduğu tespit edilmiştir (Önder, 2019).

Özer (2019) ise çalışmasında tüketicilerin görsel açıdan algılarının marka üzerindeki etkisi anlamına gelen arketipsel marka üzerine çalışmıştır. Çalışmada arketiplerin tüketiciler üzerindeki nasıl bir etkisi olduğunu Türk menşeili markalar üzerinde incelemiştir. Bu amaçla araştırmada Kırşehir ilindeki 18-65 yaş aralığında 369 kişiye anket uygulanmıştır. Tüketicilerin şampuan markalarıyla ilgili düşüncelerinin alındığ 1 bu çalışmada tüketicilerin 12 arketipten en fazla "yaratıcı" arketipi seçtiği tespit edilmiştir.

Tüketici temelli marka değeri boyutlarının tüketicilerin taklit markalı ürün algıları üzerindeki etkilerini belirlemeyi amaçlayan çalışmanın ana kütlesini ise Gümüşhane Üniversitesi merkez kampüsünde öğrenim gören öğrenciler oluşturmaktadır. Çalışmanın uygulama bölümü için öğrencilere yüz yüze anket yapılmıştır. Analizler sonucunda marka değerinin boyutlarının tüketicilerde taklit markalı ürün algıları üzerinde anlamlı ve pozitif bir etkisi olduğu tespit edilmiştir (Yıldız ve Avcı, 2019).

Yıldız ve Günaydın (2019) ise marka konusunda birçok unsura değinmiştir. Bu unsurlar arasında marka güven, marka çağrışımları, marka farkındalığı, marka imajı bulunmaktadır. Bu değişkenlerin algılanan kalitenin marka aşkı üzerindeki etkileri araştırılmıştır. Çalışmada 2018 yılı içinde satış miktarı açısından fazla müşteri kitlesine sahip olan akıllı telefon kullanıcılardan 400 kullanıcıya anket uygulanmıştır. Analizler sonucunda bahsedilen marka unsurlarının (marka güveni, marka imajı vb.) marka aşkı üzerin- 
de anlamlı ve pozitif bir etkisi olduğu anlaşılmıştır.

Çalışmanın konusu ile ilgili Yıldız ve Koçan (2019) tarafından yapılan çalışmada ise tüketici etnosentrizmi, algılanan kalite ve marka sadakatinin marka kişiliği üzerindeki etkileri araştırılmıştır. Doğu Karadeniz Bölgesi'nde (Artvin, Rize, Trabzon ve Gümüşhane) ikamet eden krem çikolata tüketicilerinden kolayda örneklem yöntemi ile belirlenen 806 kişiye yüz yüze anket uygulanmıştır. Çalışmanın sonuçlarına bakıldığında ise genel olarak tüketici etnosentrizmi, algılanan kalite ve marka sadakatinin marka kişiliği üzerinde anlamlı bir etkisi olduğu görülmüştür. Yine analizler sonucunda tüketici etnosentrizminin marka sadakati ve algılanan kalite üzerinde anlamlı bir etkiye sahip olduğu anlaşılmıştır.

Yüce vd. (2019) tarafindan yapılan çalışmada da tüketici temelli marka değerine nostalji eğiliminin etkisinin olup olmadığının ortaya çıkarılması amaçlanmıştır. Araştırma için doğu ekspresi ile seyahat eden 415 bireye anket yöntemi uygulanmıştır. Çalışma sonucunda nostalji eğilimi; tüketici temelli marka değerinin alt boyutlarını anlamlı bir şekilde etkilediği ifade edilmektedir. Nostalji eğiliminin demografik özellikler açısından farklılık göstermediği sadece yaşa göre farklılık gösterdiği sonucuna ulaşılmıştır.

Bir diğer çalışmada ise Türk reklamlarında ünlü kullanımı tüketicilerin satın alma niyeti ve markaya duydukları sadakat üzerindeki etkisi olup olmadığı incelenmiştir. Ayrıca marka sadakatinin satın alma niyeti üzerindeki etkisi de araştırılmıştır. Çalışmanın ana kütlesini Konya Selçuk Üniversitesi iktisadi ve idari bilimler fakültesi 2018- 2019 öğretim yılında eğitim alan öğrenciler oluşturmaktadır. Çalışmanın uygulama bölümünde veri toplamak için anket yöntemi kullanılmıştır. Çalışma sonucunda ünlülerin yer aldığı marka reklamlarının satın alma niyeti ve marka sadakati üzerinde anlamlı bir etkisi olduğu anlaşılmıştır. Bu anlamda ünlülerin oynadıkları marka reklamlarının tüketiciler açısından pozitif bir etkiye sahip olduğu vurgulanmıștır. Son olarak marka sadakatinin satın alma niyetini de etkilediği sonucuna varılmıştır (Ahmedov, 2020).

Konuyla ilgili bir diğer çalışmada ise marka performansı ve kurumsal sürdürülebilirlik performansı arasındaki ilişkiyi analiz etmeyi amaçlanmıştır. Ayrıca kurumsal sürdürülebilirlik performansının marka performansı üzerindeki etkisi araştırılmıştır. Çalışmada Borsa İstanbul 100 (BIST 100) Endeksi'nde 2014-2018 yılları arasında faaliyette bulunan, 63 işletme örneklem olarak seçilmiş panel logit ve panel probit yöntemleri ile analize tabi tutulmuştur. Çalışma sonucunda kurumsal sürdürülebilirlik performansı değişkeninin marka performansı üzerinde anlamlı bir etkisi olduğu tespit edilmiştir. Yine araştırma sonunda marka performansı yüksek olan işletmelerin sürdürülebilirlik performansta daha yüksek seviyede oldukları tespit edilmiștir (Aksoy, 2020).

Genel kurumsal sosyal sorumluluk algısı, genel iş etiği algısı, marka tutumu ve satın alma niyeti arasındaki ilişkiyi açıklayan çalışma ise Nivea markasını kullanan ve 
bilen 18 yaşından büyük katılımcılara anket yöntemi kullanılarak gerçekleştirilmiştir. Çalışma sonucunda değişkenler arasında pozitif anlamlı bir ilişki tespit edilmiştir (Altan ve Gürce, 2020).

Avcı ve Keser (2020) ise çalışmalarında marka prestiji ve marka kredibilitesinin, tüketici temelli marka değeri üzerindeki etkisini araştırmıştır. Araştırma Diyarbakır ilinde yaşayan 18 yaş ve üzerindeki GSM operatörü kullanıcısı 494 kişiye anket yöntemi uygulanarak gerçekleștirilmiştir. Yapılan analiz sonucunda bahsi geçen değişkenler arasında anlamlı ve pozitif bir ilişki tespit edilmiştir. Ayrıca kullanıcıların marka prestiji, marka kredibilitesi ve tüketici temelli marka değeri boyutlarına ilişkin düzeyleri arasında anlam11 bir farklılık olduğu belirtilmiştir.

Marka konulu bir diğer çalışmada ise Demirağ ve Çavuşoğlu (2020) tüketicilerin marka kaçınması boyutlarının marka nefreti üzerindeki etkisi belirlenmeye çalışılmıştır. Çalışma Gaziantep'te spor giyim markalarını tercih eden ve herhangi bir nedenle marka satın almaktan kaçınan /nefret eden 427 tüketiciye anket yöntemi uygulanarak gerçekleştirilmiştir. Analiz sonuçlarına göre gibi marka kaçınması boyutlarının (eksik değer, deneyimsel, kimlik, ahlaki boyut) marka nefreti üzerinde pozitif ve anlamlı bir etkisi olduğu anlaşılmıştır. Yine bulgulardan bir diğeri ise satın alma niyetinin marka nefretinin negatif bir şekilde etkilediğidir.

Dülek ve Aydın (2020) tarafindan da marka sadakati, elektronik ağızdan iletişim ve satın alma niyeti üzerinde sosyal medya pazarlamasının etkili olup olmadığı, ayrıca marka sadakati ve elektronik ağızdan iletişimin satın alma niyeti üzerindeki etkisi araştırılmıştır. Araştırmanın örneklemini Van Yüzüncü Yıl Üniversitesi’nde öğrenim gören ve ürünlerin sosyal medyada takibini yapan ve alışveriş yapan 375 öğrenci oluşturmaktadır. Çalışmada, sosyal medya pazarlamasının satın alma niyeti üzerinde olumlu bir etkisi olmadığı belirlenmiştir. Ayrıca marka sadakatinin elektronik ağızdan ağıza iletişim ve satın alma niyeti üzerinde olumlu bir etkisi olduğu belirlenmiştir.

Konuyla ilgili bir diğer çalışmada ise kozmetik vb. ürünlerle ilgili etkileyicilik yapan kişilerin tüketicileri etkileyip etkilemediği belirlenmeye çalışılmıştır. Bu anlamda etkileyici kişinin (Görkem Karman) deneyimlerinin tüketicilerin marka imajları üzerindeki etkisini araştırmak için 223 takipçi yorumuna yönelik içerik analizi yapılmıştır. Çalışma sonucunda Görkem Karman'ın ürünler hakkındaki yorumlarının katılımcıları olumlu olarak etkilediği sonucuna ulaşılmıştır. Etkileyici kişilerin tüketicileri satın almaya teşvik ettiği sonucuna da ulaşılmıştır (Efe ve Venture, 2020).

Marka ile ilgili bir diğer çalışmada da Ankara'da yaşayan genç katılımcıların (14 -19 yaş aralığı) spor ayakkabısı marka tercihlerini ortaya konulmaya çalışılmıştır. Ayrıca katılımcıların marka sadakati ve spor ayakkabı markalarının piyasa içerisindeki konumunun belirlenmesini amaçlamıştır. Araştırmanın örneklemini 217 genç tüketici 
oluşturmaktadır. Çalışmada markov zincirleri analizi yapılmıştır. Araştırma sonucunda, marka bağlılığının en fazla Nike firmasına olduğu anlaşılmıştır. Nike firmasını sırasıyla Adidas, Reebok, Skechers, Puma ve New Balance takip etmektedir (Ercan, 2020).

Eren (2020) ise çalışmasında e- ticaret yapan markaların satış promosyonlarının, marka ederini oluşturan unsurlar üzerindeki etkisini araştırmıştır. Ayrıca marka sadakatinin öncülleri araştırması da yapılmıştır. Araştırma Ankara' da bulunan 452 kişinin katılımı ile yüz yüze anket yöntemi uygulanarak yapılmıştır. Araştırma sonuçlarına göre parasal olmayan satış promosyonları algılanan kalite, marka farkındalığı ve marka sadakati üzerinde olumlu etkiye sahip olduğu anlaşılmıştır. Ayrıca parasal satış promosyonlarının da marka farkındalığı üzerinde olumlu etkiye sahip olduğu belirtilmiştir. Son olarak marka farkındalığının algılanan kalite ve marka çağrışımları üzerinde olumlu etkisi olduğu tespit edilmiştir.

Türkiye' deki otomotiv sektörünün marka bağlılığının oluşumunu inceleyen araştırmada ise bir otomobil markasının Türkiye hayran sayfası netnografi yöntemi kullanılarak analiz edilmiştir. Araştırma sonucunda davranışsal marka bağlılığının olumlu tutumlar ile desteklenmesi ile Türkiye'deki otomotiv sektöründe gerçek bir marka bağlılığının oluşabileceği sonucuna varılmıştır (Dalgıç ve Tiltay, 2020).

Çalışmalarında marka değeri ile kurumsal itibar ilişkisini inceleyen İpçioğlu ve Arpa (2020) ise marka değerinin kurumsal itibar üzerindeki etkisini tespit etmeyi amaçlamışlardır. Araştırma için Bereket Emeklilik ve Hayat Anonim Şirketi’nin müşterilerinden 1500' üne anket gönderilmiş 420 tanesinden geri dönüş alınmıştır. Çalışmadan elde edilen verilere dayanarak marka değeri ve kurumsal itibar arasında ilişki tespit edilmiş ve marka değerinin kurumsal itibar üzerinde etkili olduğu sonucuna ulaşılmıştır.

Özhan ve Yüksek (2020) ise Türkiye' de yaygın olarak kullanılan üç GSM operatöründen, 2017- 2020 yılları arasında bu operatörlerden hizmet alan ve bu hizmet sağlayıcıları bu dönemde değiştirmeyen ve değiştiren tüketiciler üzerinde karşılaştırma yapmıştır. Çalışmada katılımcıların kullandıkları GSM firmasının marka kişiliği ile hizmet almadıkları GSM firması marka kişilikleri incelenerek, bu değişkenin marka kişiliği algısı üzerindeki etkisi araştırılmıştır. Çalışmanın uygulama bölümü İstanbul'da yaşayan 18 yaş ve üzeri tüketicilere anket uygulanarak gerçekleştirilmiştir. Analizler sonucunda, GSM operatörlerini deneyim değişkeninin, algılanan marka kişiliği algısını negatif yönde etkilediği sonucuna varılmıştır.

Özden (2020) tarafindan yapılan çalışmada ise farklı kültürlerden olan tüketicilerin, başkalarını affetme eğilimleri ile marka sadakatleri arasındaki ilişki incelenmiştir. Çalışma Türkiye ve Azerbaycan'dan toplam 735 tüketiciye anket yöntemi uygulanarak oluşturulmuştur. Tüketicilerin affetme eğilimi düşük veya yüksek olsa da marka ile yaşanılan sorun tatmin edici şekilde çözüldüğünde, marka sadakatleri yüksek olmaktadır. Bu 
durumda, tüketicilerin markaları kahramanlaștırdıkları ve markalara sadakat gösterdikleri sonucuna ulaşılmıştır.

Paksoy vd. (2020) ise çalışmalarında üniversitelerde akademik kadrolarda çalışanların marka değerinin belirlenmesine yönelik bir ölçek geliştirmeyi amaçlamışlardır. Buradan hareketle ilgili yazın tarandıktan sonra konuyla ilgili bir model geliștirilmeye çalışılmıştır. Geliştirilen model ile Amerika'daki bir üniversitenin akademisyenlerinin marka değeri ölçülmüştür.

Bir jeans markasına yönelik marka kişiliği algılarının benlik saygısı üzerindeki etkisini ve marka kişiliği algıları ve benlik saygısı düzeylerinin satın alma tarzları üzerindeki etkisini araştıran çalışma ise Kayseri Nuh Naci Yazgan Üniversitesi'nde öğrenim gören 375 lisans öğrencisine yüz yüze anket yöntemi uygulanarak gerçekleștirilmiștir. Araştırmanın bulgularına göre, tüketicilerin marka kişiliği algılarının benlik saygıları ve satın alma tarzı üzerinde anlamlı bir etkisinin olduğu belirlenmiş ve benlik saygısının tüketicilerin satın alma tarzı üzerinde anlamlı bir etkisinin olmadığg belirtilmiştir (Sargın ve Koçer, 2020).

Yıldız ve Kırmızıbiber (2020) ise marka logoları üzerine araştırma yapmıştır. Çalışmada marka logolarının önemi, marka logolarının faktörleri ve bu faktörlerin özgün bir marka oluşturmadaki etkisi üzerinde yoğunlaşmışlardır. Araştırma Erzurum ilinde yaşayan beyaz eşya sahibi 500 tüketiciye anket yöntemi uygulanarak gerçekleştirilmiştir. Çalışma sonucunda marka logosunu oluşturan faktörler ile marka özgünlüğü arasında olumlu ve anlamlı bir ilişki tespit edilmiștir.

Bir diğer çalışmada Yılmazer ve Nart (2020) tüketiciler açısından marka değeri boyutlarının marka sadakati üzerindeki etkisini incelemiştir. Araştırma, Türkiye'de bulunan erkek giyim sektörü markalarını tercih eden 318 erkek tüketici ile online anket yöntemi uygulanarak gerçekleştirilmiştir. Çalışma da tüketici açısından marka değerinin 7 boyutunun bulunduğu ve bu boyutların marka sadakati üzerinde pozitif açıdan etkili olduğu tespit edilmiştir.

Uğur ve Sarığlu (2020) yaptıkları çalışmada ise tüketicilerin ortaya koydukları kişilik özellikleri ile marka değiştirme durumları ilişkisi araştırılmıştır. Çalışma, Cumhuriyet Üniversitesi Gemerek Meslek Yüksekokulu'ndaki aktif olarak öğretime devam eden 315 öğrenciye kolayda örnekleme yöntemi uygulanarak gerçekleştirilmiştir. Çalışmada marka değiştirme davranışı üzerinde gelişime açıklığın etkili olduğu tespit edilirken özdenetimin marka değiştirme davranışına etkisinin olmadığı görülmüştür.

Bağdat ve Arıkan (2021) ise marka denkliği konusunu incelemişlerdir. Çalışmalarında birçok faktörün marka denkliğinin bileşenleri üzerindeki etkilerini incelemişlerdir. $\mathrm{Bu}$ faktörler arasında reklam harcamaları, bütünleşik pazarlama iletişimi, reklam tutumu ve parasal satış promosyonlarıdır. Çalışmanın örneklemini havayolu taşımacılığı sektörü 
oluşturmaktadır. Bu sektördeki işletmelerden elde edilen 403 anket analize tabi tutulmuştur. Çalışma sonucunda yukarıda ifade edilen faktörlerin marka denkliği üzerinde etkisinin olduğu tespit edilmiştir.

Çağlıyan ve Yılmaz (2021) ise tüketicilerin algıladığı yenilikçilik düzeyi, markaya duyulan güven ve müşteri sadakati arasındaki ilişkiyi incelemiştir. Araştırmada tüketici olarak Selçuk Üniversitesi'nde tam zamanlı olarak çalışan toplam 2200 akademisyen seçilmiştir. Çalışmanın uygulama bölümü Mart-Nisan 2019 tarihleri arasında anket yöntemi ile gerçekleştirilmiştir. Araştırma sonucunda katılımcıların algılanan yenilikçilik düzeyi, müşteri memnuniyeti ve müşteri sadakati arasında anlamlı bir ilişki bulunmuştur.

Çelikkol (2021) tarafından yapılan çalışmada ise tüketicilerin satın alma niyetini etkileyen faktörlerin tespit edilmesi amaçlanmıştır. Ayrıca çalışmada marka bağımlılığı ve satın alma niyeti arasında ilişki olup olmadığ 1 da tespit edilmek istenmiştir. Araştırmada kolayda örneklem yöntemi ile 20-30 yaș aralığındaki İstanbul/Kadıköy ikameti olan genç yetişkinlere anket uygulaması gerçekleştirilmiştir. Analiz sonuçlarına göre tüketicilerin marka bağımlılığının satın alma niyeti üzerinde anlamlı ve olumlu bir etkisinin olduğu tespit edilmiştir.

Doğanlı (2021) ise çalışmasında, perakende sektörü içinde yer alan marketlerin tercih edilmesi/edilmemesinde tüketicilerin özelliklerini (demografik özellikler, kişisel özellikler, tüketim tercihleri, sosyoekonomik konumlarını, alış-veriş tercihleri) ortaya koymaya çalışmıştır. Çalışmanın ana kütlesini market markası tercih eden/etmeyen müşteriler oluşturmaktadır. Analiz sonucunda tüketiciler üç kümede sınıflandırılmıştır. İlk gruptaki bireylerin, market markalarının kaliteli olmadığını düşündüğü ve fiyatın kalite ile ilişkili olduğu görüşünü desteklediği belirtilmiştir. İkinci sınıflandırmayı oluşturan bireyler ise gelir açısından orta seviyede olan kalite algısını önemseyen ve fiyatların makul olduğunu düşünmektedir. Son gruptaki tüketicilerin ise gelir açısından düşük ve eğitim imkanları açısından yetersiz durumdadırlar. Bu gruptaki tüketiciler, ürünlerin marka değerini yüksek bulup, ürün çeșitliliğinin iyi düzeyde ve kaliteli olduğunu düşünmektedirler.

Marka konulu bir diğer çalışmada ise tüketicilerin markadan kaçınma durumlarına ilişkin algılamalarının demografik özelliklere göre farklılık gösterip göstermediği analiz edilmiştir. Çalışmada Van ilindeki 655 GSM operatörü kullanıcısı olan tüketicilerin marka kaçınma davranışları incelenmiştir. Veri toplama yöntemlerinden anket kullanılmıştır. Çalışma sonucunda tüketicilerin marka kaçınma davranışlarının medeni durum, eğitim düzeyi ve gelir seviyesi değişkenlerine göre farklılık gösterdiği tespit edilmiştir (Dülek, 2021).

İrfanoğlu (2021) ise çalışmasında tüketicilerin satın alma durumlarının iyi olmasına karşın tüketim durumlarının neden azalttıklarını literatürde yer alan araştırmalardan 
faydalanarak açılamıştır. Araştırma sonucunda marka kaçınmasının tüketicilerin tüketmeme eğilimlerinin altında yatan nedenlerin psikolojik ve sosyolojik olduğu saptanmıştır.

Marangoz ve Aydın (2021) çalışmalarında otantikliği, marka aşkı ve marka sadakati kavramlarının birbirleri arasındaki ilişkiyi değerlendirmişlerdir. Çalışmada Türkiye'de kozmetik ürün kullanan tüketicilere kolayda örnekleme yöntemiyle 384 tüketiciden sağlanan verilerle korelasyon, regresyon ve hiyerarşik regresyon analizi yapılmıştır. Yapılan analizler sonucu marka otantikliğinin marka aşkı ve marka sadakati üzerinde olumlu yönde etkili olduğu anlaşılmıştır. Ayrıca süreklilik boyutu ile marka sadakati arasındaki ilişkide marka aşkının düzenleyici bir etkisi olduğu da belirtilmiştir.

Marka evangelizminin oluşumunda marka bilgisi ve tüketici-marka ilginliğinin etkisinin belirlenmesi ve bu ilişkide dişa dönüklük ile deneyime açıklık kişilik özelliklerinin rolünün ortaya konulan çalışma ile ilgili bilgiler ise şu şekildedir. Çalışmada Samsung, Apple iPhone ve Huawei marka cep telefonu kullanan 518 tüketiciye kolayda örneklem yöntemi kullanılarak online anket uygulanmıştır. Araştırma sonunda marka bilgisinin hem tüketici-marka ilginliği üzerinde hem de marka evangelizmi üzerinde olumlu etkisi olduğu görülmüştür. Bununla birlikte tüketici-marka ilginliğinin marka evangelizmi üzerinde olumlu bir etki saptanmıştır. Ayrıca bu etkilerde dışa dönüklük ve deneyime açıklık kişilik özelliklerinin rolü de belirlenmiştir (Meriç ve Yüce, 2021).

Özdemir vd. (2021) ise çalışmasında pandemi (COVID-19) dönemi ile ilgili marka konusunu araştırmıştır. Çalışmada elektronik ortamdaki iletişimde marka imajı ve tüketicilerin satın alma niyeti üzerindeki etkisi araştırılmıştır. 567 Instagram kullanıcısına online anket yöntemi uygulanmıştır. Yapılan analiz sonucunda marka imajı, E-WOM ve tüketici satın alma niyeti faktörlerinin birbirleri arasında güçlü bir ilişki tespit edilmiştir.

Konuyla ilgili bir diğer çalışmada, reklam müziğinin marka bilinirliği oluşturması ve müşterilerin satın alma niyetleri üzerindeki etkisi incelenmiştir. Türkiye'de televizyon reklamlarını izleyen kişilere 15 Şubat 2021 ile 9 Mart 2021 tarihleri arasında çevrimiçi anket çalışması uygulanmıştır. Çalışma sonucunda reklam müziğinin marka bilinirliğinde ve satın alma niyetinde etkili olduğu tespit edilmiştir (Öztürk ve Balyaş, 2021).

Marka konusunda bir diğer çalışmada ise tüketicilerin markalara yönelik olumsuz duygularından olan marka nefreti kavramını, marka misillemesi bağlamında incelemek ve ortaya çımasında etkili olan faktörleri belirlemek amaçlanmıştır. Çalı̧̧ma Manisa il merkezinde bulunan ve herhangi bir markaya yönelik nefret duygusu geliştiren 300 tüketiciye yüz yüze anket yöntemi uygulanarak oluşturulmuştur. Analiz sonuçları doğrultusunda sembolik uyumsuzluğun marka nefreti üzerinde, marka nefretinin ise marka misillemesi ve olumsuz ağızdan ağıza iletişim üzerinde anlamlı bir etkisi bulunduğu tespit edilmiştir (Ünal, 2021).

Tüketicilerin marka sadakati ve markaya yönelik kalite algılarının ağızdan ağıza 
pazarlama faaliyetleri üzerindeki etkisini araştıran çalı̧̧ma ise Muğla ili ve çevresinde DeFacto hazır giyim markasını kullanan 525 tüketiciye anket yöntemi uygulanarak gerçekleştirilmiştir. Marka sadakati ve algılanan kalitenin, tüketicilerin pozitif ağızdan ağıza pazarlama faaliyetlerinde olumlu etkisinin olduğu, negatif ağızdan ağıza pazarlama faaliyetlerini ise azalttığı sonucuna ulaşılmıştır. Sonuç olarak, tüketicilerin ağızdan ağıza pazarlama faaliyetlerinde marka sadakati ve kalite algılarının etkili olduğu tespit edilmiştir (Türk, 2021).

Soyaltin ve Türkyılmaz (2021) ise uluslararası bir kongreye hazırlamış oldukları bildirilerinde nöro pazarlama yöntemi ile tüketicilerin retro müziklere olan tepkilerini ölçmektedir. Çalışma ile retro müziklerin müşterilerin marka değerlendirmelerinde algıyı ne derece etkilediğini, bilinçaltındaki düşünceleri ortaya çıkararak tespit etmeye çalışmaktadır. Çalışmanın uygulama bölümü devam etmektedir. Araştırmada nicel araştırma yöntemi uygulanacak olup veri toplama tekniği olarak da anket tekniği (300 kişiye) tercih edilmiştir.

Son olarak Yayman (2021) ise bankaların, bireysel faaliyetlerinin, marka imajları, hizmet kalitesi, müşteri tatmini ve bağlllı̆ı, müssteri değeri üzerindeki etkilerini incelemiştir. Çalışma, Tekirdağ' daki 18 yaş üstü banka müşterilerinden bireysel 752 müşteriye anket yöntemi uygulanarak gerçekleştirilmiştir. Çalışma marka ve hizmet kalitesi ile ilgili literatüre katkı sağlamak amacıyla teorik bilgiler sunmaktadır. Ayrıca çalışmada bankacılık sektöründeki ilgililere de rekabet avantajı yakalama konusunda bilgiler verilmektedir.

İncelenen literatür taramasında çalışmaların büyük çoğunluğunun nicel araştırma yöntemleri uygulanarak yapıldığı ve markanın farklı değişkenler üzerindeki etkisinin ölçüldüğü anlaşılmaktadır. Çalışmalardan sadece bir tanesinin literatür taraması şeklinde hazırlandığı ve sadece doktora tezlerinin incelendiği anlaşıldığından ilgili yazında bu boşluğun doldurulması istenmektedir.

\section{ARAŞTIRMANIN YÖNTEMI}

$\mathrm{Bu}$ çalışma ile sürdürülebilir rekabet etmede işletmelerin dikkat etmesi gereken önemli faaliyet alanı olan marka ile ilgili makalelerin literatür incelenmesinin yapılmaS1 amaçlanmıştır. Araştırmada verilerin tanımlanması, incelenmesi, sınıflandırılması ve yorumlanması işleminde makalelerin orijinalliklerine bağlı kalınarak doküman analizi yapılmıştır. Çalışmada 2013-2021 yılları arasında DergiPark'da marka konusunda yayımlanmış olan makaleler tam sayım yöntemi ile belirlenmiştir.

Bilimsel çalışmaların önemli bir platformu olan DergiPark'da yayımlanan makalelerin incelenmesinde şu şekilde bir filtreleme yapılmıştır:

DergiPark arama butonundan marka kelimesi girilmiştir. Marka kelimesi makale filtresi kullanılarak aranmıştır. Konu olarak işletme işaretlenmiştir. Desteklenen dil olarak İngilizce ve Türkçe seçilmiş, arama alanlarında başlık ve anahtar kelimeler; makale 
türünde, araştırma makalesi; yayınlanma tarihinde güncel olanların incelenmesine yönelik 2013 ve sonrası seçilmiştir. Bu filtreleme sonucunda 61 makaleye ulaşılmıştır. 61 makale yazar adı, ulusal/uluslararası olma, yayım dili, araştırma yöntemi, marka konusu ve yayım yılı şeklinde literatür incelemesine tabi tutulmuştur.

\section{ARAŞTIRMANIN BULGULARI}

Marka çerçevesinde ulusal yazında yapılan işletme alanındaki makale çalışmaları incelenmesi sonucu çalışmalar analiz edilmiştir. DergiPark da 2013 ve sonrası dönemlerde yayımlanmış olan marka konulu makaleler Tablo 1'deki gibidir.

Tablo 1: Marka Konulu Akademik Çalışmalar

\begin{tabular}{|c|c|c|c|c|c|c|}
\hline Sayı & Yazar & \begin{tabular}{|l|} 
Ulusal/ \\
Uluslararası
\end{tabular} & Yayım Dili & $\begin{array}{l}\text { Araştırma } \\
\text { Yöntemi }\end{array}$ & Marka Konusu & $\begin{array}{l}\text { Yayım } \\
\text { Yılı }\end{array}$ \\
\hline 1 & $\begin{array}{l}\text { Baş, M. ve Şa- } \\
\text { hin, Ş. }\end{array}$ & Ulusal & Türkçe & Nicel & $\begin{array}{l}\text { E-Ticaret ve } \\
\text { Marka }\end{array}$ & 2013 \\
\hline 2 & Güzel, F.Ö. & $\begin{array}{l}\text { Uluslara- } \\
\text { rasi }\end{array}$ & Türkçe & Nitel & Marka İtibarı & 2014 \\
\hline 3 & $\begin{array}{l}\text { Karataş, Ö.N. ve } \\
\text { Bekçi, I. }\end{array}$ & Ulusal & Türkçe & Nicel & Marka Değeri & 2017 \\
\hline 4 & Onan, G. & Ulusal & Türkçe & Nicel & Marka Sadakati & 2017 \\
\hline 5 & Sarıçiçek, R. vd. & Ulusal & Türkçe & Nicel & $\begin{array}{l}\text { Marka İmajı ve } \\
\text { Kimliği }\end{array}$ & 2017 \\
\hline 6 & $\begin{array}{l}\text { Koçan, M. ve } \\
\text { Gerekan, B. }\end{array}$ & Ulusal & Türkçe & Nicel & Marka Değeri & 2017 \\
\hline 7 & Aksoy, H. & Ulusal & Türkçe & Nicel & Marka İmajı & 2018 \\
\hline 8 & Çakır, M. & Ulusal & Türkçe & Nitel & $\begin{array}{l}\text { Marka } \\
\text { Farkındalığ } 1\end{array}$ & 2018 \\
\hline 9 & $\begin{array}{l}\text { Yaprak, İ. ve } \\
\text { Dursun, Y. }\end{array}$ & Ulusal & Türkçe & Nicel & Marka Sadakati & 2018 \\
\hline 10 & Atıgan, F. & Ulusal & Türkçe & Nicel & Marka Kişiliği & 2019 \\
\hline 11 & $\begin{array}{l}\text { Akgün, V.Ö. ve } \\
\text { Tekin, M. }\end{array}$ & Ulusal & Türkçe & Nicel & Marka Değeri & 2019 \\
\hline 12 & Ercis, A. vd. & Ulusal & Türkçe & Nicel & Marka Sadakati & 2019 \\
\hline 13 & Deniz, E. & Ulusal & Türkçe & Nicel & $\begin{array}{l}\text { Marka İmajı ve } \\
\text { Değeri }\end{array}$ & 2019 \\
\hline 14 & Çınar, D. & Ulusal & Türkçe & Nicel & Marka Sadakati & 2019 \\
\hline 15 & $\begin{array}{l}\text { Aslan, R. ve Öz- } \\
\text { beyaz, A. }\end{array}$ & Ulusal & Türkçe & Nicel & Marka Etkisi & 2019 \\
\hline 16 & $\begin{array}{l}\text { Balıkçıoğlu, B. } \\
\text { ve Kiyak,F. }\end{array}$ & Ulusal & Türkçe & Nicel & Marka Nefreti & 2019 \\
\hline 17 & Önder, C. & Ulusal & Türkçe & Nitel & Marka Değeri & 2019 \\
\hline
\end{tabular}




\begin{tabular}{|c|c|c|c|c|c|c|}
\hline 18 & Özer, Ö. & Ulusal & Türkçe & Nicel & $\begin{array}{l}\text { Arketipsel Mar- } \\
\text { ka }\end{array}$ & 2019 \\
\hline 19 & $\begin{array}{lll}\text { Yıldız, } & \text { S. } & \text { ve } \\
\text { Avc1, I. } & & \end{array}$ & Ulusal & Türkçe & Nicel & Marka Değeri & 2019 \\
\hline 20 & $\begin{array}{l}\text { Yildız, E. ve } \\
\text { Günaydın, R. }\end{array}$ & Ulusal & Türkçe & Nicel & $\begin{array}{l}\text { Marka Çağrı- } \\
\text { şımları, Marka } \\
\text { Farkındalığ } 1, \\
\text { Marka İmajı, } \\
\text { Marka Güveni, } \\
\text { Marka Aşkı } \\
\end{array}$ & 2019 \\
\hline 21 & $\begin{array}{l}\text { Emel Yildız, E. } \\
\text { ve Koçan, M. }\end{array}$ & Ulusal & Türkçe & Nicel & Marka Sadakati & 2019 \\
\hline 22 & $\begin{array}{l}\text { Görbüz, E. ve } \\
\text { Başkol, M. }\end{array}$ & Ulusal & Türkçe & Nicel & Marka Sadakati & 2019 \\
\hline 23 & $\begin{array}{l}\text { Elagöz, İ. ve } \\
\text { Yücekaya, P. }\end{array}$ & Ulusal & Türkçe & Nicel & Marka Değeri & 2019 \\
\hline 24 & $\begin{array}{l}\text { Demirağ, B. ve } \\
\text { Çavuşoğlu,S. }\end{array}$ & Ulusal & Türkçe & Nicel & Marka Sadakati & 2019 \\
\hline 25 & Çifci, S. vd. & Ulusal & Türkçe & Nicel & \begin{tabular}{|l} 
E ticaret ve \\
Marka
\end{tabular} & 2019 \\
\hline 26 & $\begin{array}{l}\text { Kahraman, M.A } \\
\text { ve Dağl1, S. }\end{array}$ & Ulusal & Türkçe & Nicel & Marka Alg1s1 & 2019 \\
\hline 27 & $\begin{array}{l}\text { Koçak, A. ve } \\
\text { Bayraktar, A. }\end{array}$ & Ulusal & Türkçe & Nicel & Marka Kimliği & 2019 \\
\hline 28 & Öcel, Y. & Ulusal & Türkçe & Nicel & \begin{tabular}{|l} 
Literatür Tara- \\
ması
\end{tabular} & 2019 \\
\hline 29 & Yüce, A. vd. & $\begin{array}{l}\text { Uluslara- } \\
\text { rası }\end{array}$ & Türkçe & Nicel & Marka Değeri & 2019 \\
\hline 30 & Ahmedov, A. & Ulusal & Türkçe & Nicel & Marka Sadakati & 2020 \\
\hline 31 & Aksoy, M. & Ulusal & Türkçe & Nicel & $\begin{array}{l}\text { Marka Perfor- } \\
\text { mansı ve Değeri }\end{array}$ & 2020 \\
\hline 32 & $\begin{array}{l}\text { Altan, Y. ve } \\
\text { Gürce, M.Y. }\end{array}$ & Ulusal & Türkçe & Nicel & Marka Tutumu & 2020 \\
\hline 33 & $\begin{array}{l}\text { Yildiz, E. ve } \\
\text { Kirmizibiber, A. }\end{array}$ & Ulusal & Türkçe & Nicel & Marka Kişiliği & 2020 \\
\hline 34 & $\begin{array}{l}\text { Yilmazer, E. ve } \\
\text { Nart, S. }\end{array}$ & Ulusal & Türkçe & Nicel & Marka Değeri & 2020 \\
\hline 35 & $\begin{array}{l}\text { Avc1, M. ve Ke- } \\
\text { ser, E. }\end{array}$ & Ulusal & Türkçe & Nicel & Marka Değeri & 2020 \\
\hline 36 & Özden, A.T. & Ulusal & İngilizce & Nicel & Marka Sadakati & 2020 \\
\hline 37 & $\begin{array}{l}\text { Demirağ, B. ve } \\
\text { Çavuşoğlu, S. }\end{array}$ & Ulusal & Türkçe & Nicel & Marka Nefreti & 2020 \\
\hline
\end{tabular}




\begin{tabular}{|c|c|c|c|c|c|c|}
\hline 38 & $\begin{array}{l}\text { Dülek, B. ve Ay- } \\
\text { dın, İ. }\end{array}$ & $\begin{array}{l}\text { Uluslara- } \\
\text { rasi }\end{array}$ & İngilizce & Nicel & $\begin{array}{l}\text { Elektronik Ti- } \\
\text { caret ve Marka } \\
\text { Sadakati }\end{array}$ & 2020 \\
\hline 39 & $\begin{array}{l}\text { Efe, A. ve Ven- } \\
\text { tura, K. }\end{array}$ & Ulusal & Türkçe & Nitel & Marka İmajı & 2020 \\
\hline 40 & Ercan, Ö. & Ulusal & Türkçe & Nicel & Marka Sadakati & 2020 \\
\hline 41 & Eren, B.A. & Ulusal & Türkçe & Nicel & Marka Sadakati & 2020 \\
\hline 42 & \begin{tabular}{|ll} 
Dalgıç, T. ve \\
Tiltay, M.A
\end{tabular} & Ulusal & Türkçe & Nitel & Marka Sadakati & 2020 \\
\hline 43 & $\begin{array}{l}\text { İpçioğlu, İ. ve } \\
\text { Arpa D. }\end{array}$ & Ulusal & Türkçe & Nicel & Marka Değeri & 2020 \\
\hline 44 & $\begin{array}{l}\text { Özhan, S. ve } \\
\text { Yüksel, C.A. }\end{array}$ & Ulusal & Türkçe & Nicel & Marka Kişiliği & 2020 \\
\hline 45 & $\begin{array}{l}\text { Paksoy, H.M. } \\
\text { vd. }\end{array}$ & Ulusal & İngilizce & Nitel & Marka Değeri & 2020 \\
\hline 46 & $\begin{array}{l}\text { Sargın,S. ve Ko- } \\
\text { çer, L.L. }\end{array}$ & $\begin{array}{l}\text { Uluslara- } \\
\text { rasi }\end{array}$ & Türkçe & Nicel & Marka Kişiliği & 2020 \\
\hline 47 & $\begin{array}{l}\text { Uğur, U. ve Sa- } \\
\text { rioğlu, S. }\end{array}$ & Ulusal & Türkçe & Nicel & Marka Sadakati & 2020 \\
\hline 48 & $\begin{array}{l}\text { Çağliyan, V. ve } \\
\text { Yilmaz, N. }\end{array}$ & $\begin{array}{l}\text { Uluslara- } \\
\text { ras1 }\end{array}$ & Türkçe & Nicel & Marka Sadakati & 2020 \\
\hline 49 & Çelikkol, Ş. & Ulusal & Türkçe & Nicel & Marka Bağlılı̆g 1 & 2021 \\
\hline 50 & $\begin{array}{l}\text { Bağdat, S.G. ve } \\
\text { Arıkan, E. }\end{array}$ & Ulusal & Türkçe & Nicel & Marka Denkliği & 2021 \\
\hline 51 & Doğanl, B. & Ulusal & Türkçe & Nicel & Marka Değeri & 2021 \\
\hline 52 & Dülek, B. & Ulusal & Türkçe & Nicel & $\begin{array}{l}\text { Marka Kaçın- } \\
\text { ması }\end{array}$ & 2021 \\
\hline 53 & İrfanoğlu M. & Ulusal & Türkçe & Nitel & $\begin{array}{l}\text { Marka Kaçın- } \\
\text { ması }\end{array}$ & 2021 \\
\hline 54 & $\begin{array}{l}\text { Meriç, K. ve } \\
\text { Yüce, A. }\end{array}$ & Ulusal & Türkçe & Nicel & $\begin{array}{l}\text { Marka Evange- } \\
\text { lizmi }\end{array}$ & 2021 \\
\hline 55 & $\begin{array}{l}\text { Öztürk, A. ve } \\
\text { Balyaş, B. }\end{array}$ & Ulusal & Türkçe & Nicel & $\begin{array}{l}\text { Marka Bilinirli- } \\
\text { liği }\end{array}$ & 2021 \\
\hline 56 & Özdemir, S. vd. & $\begin{array}{l}\text { Uluslara- } \\
\text { rasi }\end{array}$ & Türkçe & Nicel & Marka İmajı & 2021 \\
\hline 57 & $\begin{array}{l}\text { Müftüoğlu, M. } \\
\text { ve Ünal, S. }\end{array}$ & Ulusal & Türkçe & Nicel & $\begin{array}{l}\text { Marka Misille- } \\
\text { mesi }\end{array}$ & 2021 \\
\hline 58 & $\begin{array}{l}\text { Marangoz, A.Y. } \\
\text { ve Aydın, A.Ö. }\end{array}$ & Ulusal & Türkçe & Nitel & $\begin{array}{l}\text { Marka Aşkı ve } \\
\text { Marka Sadakati }\end{array}$ & 2021 \\
\hline 59 & Türk, Z. & Ulusal & Türkçe & Nicel & Marka Sadakati & 2021 \\
\hline 60 & $\begin{array}{l}\text { Soyaltin, T.E. } \\
\text { ve Türkyılmaz, } \\
\text { C.A. }\end{array}$ & Ulusal & Türkçe & Nicel & $\begin{array}{l}\text { Marka Alg1la- } \\
\text { ması }\end{array}$ & 2021 \\
\hline 61 & Yayman, F. & Ulusal & Türkçe & Nicel & Marka İmaj1 & 2021 \\
\hline
\end{tabular}


Tablo 1'de marka ile ilgili 2013-2021 yılları arasında DergiPark da yayımlanmış araştırmalar sınıflandırılmıştır. Çalışmada toplam 61 makale incelenmiş olup bunlardan 58 'inin Türkçe, 3 'ününde İngilizce yayımlandığ 1 tespit edilmiştir. Araştırma yöntemlerinden en çok nicel araştırma yönteminin kullanıldığı saptanmıştır. Makalelerin yayınlanma yılı olarak en çok 2019 yılında marka ile ilgili çalışmanın yapıldığı ve yapılan çalışmaların en çok ulusal düzeyde dergilerde yayımlandığ 1 tespit edilmiştir. Ayrıca çalışmaların çoğunluğunun iki ya da daha fazla yazarlı olduğu anlaşılmaktadır. Son olarak marka konularından en çok marka sadakati ve marka değeri araştırılmış öte yandan marka kaçınması, marka evangelizmi, marka nefreti, marka misillemesi, marka algılaması gibi birçok konuya çok az yer verildiği anlaşılmaktadır. 


\section{SONUÇ}

Dünyada kıyasıya bir rekabetin yaşandığı küresel pazarlarda firmalar varlıklarını devam ettirebilmek ve farklılaşmak için çaba göstermektedirler. Ortaya konan bu çaba markaları ortaya çıkarmakta fakat güçlü markalar yaratmak ise itina ve istikrarı gerektirmektedir.

İşletmeler markalaşma sürecinde zorlu ve uzun bir yol ile karşılaşmaktadır. Markalaşmak isteyen işletmeler öncelikle pazar ortamını iyi tanımalı, tüketicilere sunacakları fikirleri, bilgileri, ürünleri ve hizmetleri tanıtabilmek için geliştirecekleri marka stratejisine odaklanmalıdır. Daha sonra yapılan araştırmalarla hitap edecekleri tüketici grubu ve tüketicinin gözünde markalarını nasıl konumlandıracaklarını belirlemelidir. Belirlenen marka her yönü ile tüketiciye açıklanmalıdır. Çünkü tüketici kendine yakın hissettiği marka hakkında detayları bilmek istemekte ve markayı sahiplenmektedir. Markalaşma sürecini başlatan işletmeler markalarını iyi yönetmeli ve ticari aksiyonlara göre güncelleme ve denetleme yapmalidır.

Çalışma sonucunda DergiPark kapsamında yayımlanan marka konulu makalelerin en çok marka sadakati ve marka değeri üzerinde yoğunlaştığı anlaşılmaktadır. Öte yandan marka evangalizmi, marka misillemesi, marka aşkı, marka denkliği, marka kaçınması, marka nefreti, marka performansı, marka çağrışımları gibi konulara oldukça az değinildiği tespit edilmiştir. Çalışma sonuçlarından bir diğeri ise çok yazarlı araştırmaların çoğunlukta olmasıdır. Çalışmaların çoğunluğunun ulusal makale olduğu da bir diğer bulgudur. Bu sonuçlarla konuyla ilgili yapılan çalışmalarla karşılaştırılması bu anlamda sadece bir tane çalışma olmasından dolayı güç olmaktadır. Literatür taraması şeklinde yapılan çalışma (Öcel, 2019) doktora tezlerinin incelenmesi şeklindedir. Çalışmanın bu literatür taraması sonuçlarına benzeyen yönleri mevcuttur. Marka konulu çalışmaların, marka değerini işlemesi, çoğunluğunun nicel çalışmalar olması bu benzer yönleri oluşturmaktadır. İleriki dönemlerde yapılan çalışmalar için marka evangelizmi, marka nefreti, marka aşkı gibi konulara daha fazla değinilmesi literatüre katkı sağlayabilir. Yine DergiPark dışındaki diğer platformlardaki makalelerinde literatür incelenmesi yapılıp karşılaştırmalar yapılabilir. Bu çalışmada, 2013-2021 yılları arasında DergiPark' ta yayımlanan makaleler değerlendirmeye alınmış olup; gerek kullanılan yöntem, gerekse incelenen konular itibariyle literatüre katkı sağlayacağı düşünülmektedir. 
Akçadağ, M., Işıksal, Z. (2021). Pazarlamada Marka Yönetimi Üzerine Literatür Taraması, Elektronik Cumhuriyet İletişim Dergisi, 2021, 3(2), 87-112.

\section{KAYNAKÇA}

Ahmedov, A. (2020). Reklamlarda ünlü ve marka arasındaki uyumun tüketicilerin satın alma niyetine ve marka sadakatine etkisi. 19 Mayss Sosyal Bilimler Dergisi, 1(2), 168-187.

Akgün, V., ve Tekin, M. (2019). Çalışanlar açısından kurumsal itibar yönetimi uygulamalarının marka değeri üzerine etkilerini ölçmeye yönelik bir saha çalışması. Gaziantep University Journal of Social Sciences, 18(2), 638-661.

Aksoy, H. (2018). Sponsor marka kimlik uyumunun marka imaj transferi üzerine etkisi: çoklu fuar sponsorluğunun analizi. Gaziantep University Journal of Social Sciences, 17(4),1456-1473.

Aksoy, M. (2020). Kurumsal sürdürülebilirlik performansı ve marka performansı arasındaki ilişki: borsa istanbul örneği. Research Journal of Business and Management, 7(3), 139-148.

Altan, T., ve Yanar Gürce, M. (2020). Genel kurumsal sosyal sorumluluk alg1S1 ve genel iş etiği algısının marka tutumu ve satın alma niyetine etkisi. 19 Mayıs Sosyal Bilimler Dergisi, 1(1)4-15.

Aslan, R., ve Özbeyaz, A. (2019). Satın alma sürecinde marka bağımlılığı üzerine bir araştırma: Adıyaman üniversitesi örneği. İnsan ve Toplum Bilimleri Araştırmaları Dergisi, 8(3), 1967-1990.

Atıgan, F. (2019). Marka kişiliğinin satın alma davranışları üzerindeki etkisi, bisküvi ve gofret sektöründe bir araştırma. Süleyman Demirel Üniversitesi Vizyoner Dergisi, 10(24), 333-348.

Avc1, M., ve Keser, E. (2020). Marka prestiji ve marka kredibilitesinin tüketici temelli marka değeri üzerindeki etkisi. Işsletme Ekonomi ve Yönetim Araştırmaları Dergisi, $3(2)$.

Balıkçığlu, B., ve Kıyak, F. (2019). Marka nefretinin nedenleri ve sonuçları üzerine Antakya'da görgül bir çalışma. Çankırı Karatekin Üniversitesi İktisadi ve İdari Bilimler Fakültesi Dergisi, 9(1), 225-243.

Baş, M., ve Şahin, Ş. (2013). Yabancı marka isimlerinin internet tüketicisinin satın alma davranışları üzerine etkisi: teknolojik ürünler üzerine bir araştırma Journal of Internet Applications And Management, 4(2), 21-47.

Çağlıyan, V., ve Yılmaz, N. (2020). Algılanan yenilikçilik, işletmeye duyulan güven ve marka sadakati üzerine bir araştırma. Bingöl Üniversitesi Sosyal Bilimler Enstitüsü Dergisi, (21), 253-276.

Çakır, M. (2018). Hizmet sektöründe marka farkındalığının avrasyalı turistik tüketiciler üzerindeki önemi: marka kentler. Kapadokya Akademik Bakış, 2(1), 61-74.

Çelikkol, Ş. (2021). Marka bağımlılığının satın alma niyetine etkisinde referans 
grubunun düzenleyici rolü: genç yetişkinler üzerine bir araştırma. Elektronik Sosyal Bilimler Dergisi, 20(78), 745-757.

Çınar, D. (2019). Dijital ortamda yapılan reklam harcamalarına yönelik algılamaların tüketici-marka bağlılığı boyutları üzerindeki etkisi. Academic Review of Humanities And Social Sciences, 2(2), 88-108.

Çifci, D., Cop, P., ve Gönenir, E. (2019). Tüketicilerin online marka topluluklarına katılımları üzerinde öz benlik uyumunun rolü. İsletme Bilimi Dergisi, 7(3), 553-573.

Dalgıç, T. ve Tiltay, M. (2020). Otomotiv sektöründe marka bağlılığı: Toyota Türkiye hayran topluluğu üzerine netnografik bir araştırma. Optimum Ekonomi ve Yönetim Bilimleri Dergisi, 7(1), 331-359.

Demirağ, B., ve Çavuşoğlu, S. (2019). Marka imajının tutumsal marka sadakati üzerindeki etkisinin incelenmesi: Bingöl otelleri örneği. Tourism and Recreation, 1(1), 15-22.

Demirağ, B., ve Çavuşoğlu, S. (2020). Marka kaçınması, marka nefreti ve satın alma niyeti arasındaki ilişkinin incelenmesi: spor giyim tercih eden tüketicilere yönelik bir araştırma. Alanya Akademik Bakış, 4(3), 577-602.

Deniz, E. (2019). Spor sponsorluğu ile marka imajı ve marka değeri arasındaki ilişki: nicel bir araştırma. Insan ve Toplum Bilimleri Araştırmaları Dergisi, 8(3), 2203-2228.

Doğanlı, B. (2021). Market markalı ürünlerin marka algısı ve tüketici kümeleri. Fiscaoeconomia, 5(1), 324-342.

Dülek, B. (2021). Tüketicilerin marka kaçınması davranışlarının demografik değişkenler açısından değerlendirilmesi: Van ili örneği. Joeep: Journal of Emerging Economies and Policy, 6(1), 222-232.

Dülek, B. ve Aydın, İ. (2020). Effect of social media marketing on e-wom, brand loyalty, and purchase intent. Bingöl Üniversitesi Sosyal Bilimler Enstitüsü Dergisi, (20), 271-288.

Efe, A. ve Ventura, K. (2020). Instagramda marka imajı yaratmada etkileyici kişiler ve müşteri etkileşimi: sponsorlu ürün yorumlarının analizine yönelik bir çalışma. Süleyman Demirel Üniversitesi Vizyoner Dergisi, 11(27), 541-554.

Elagoz, İ. ve Yücekaya, P. (2019). Ağızdan ağıza iletişimin tüketici temelli marka değerine etkisi: elektronik ürünler pazarında z nesli üzerine bir araştırma. Erzincan Binali Yıldırım Üniversitesi İktisadi ve İdari Bilimler Fakültesi Dergisi, 1(2), 94-107.

Ercan, Ö. (2020). Markov zincirleri modellemesi ile gençlerin spor ayakkabı marka tercihlerinin belirlenmesi. $R \& S$ - Research Studies Anatolia Journal, 3(2), 131-141.

Ercis, A., Aykut, O., ve Yıldız, T. (2019). Benlik-marka bağının marka sadakati üzerindeki etkisinde marka aşkı ve deneyiminin aracılık rolü. Pressacademia Procedia, 9(1), 285-294. 
Eren, B. (2020). On-line perakende sektöründe uygulanan parasal ve parasal olmayan satış promosyonlarının marka ederine etkisi. Balıkesir Üniversitesi Sosyal Bilimler Enstitüsü Dergisi, 23(44), 1133-1167.

Görbüz, E., ve Başkol, M. (2019). Perakendeci marka sadakatini etkileyen faktörlerin belirlenmesi. Yönetim Ekonomi Edebiyat Íslami ve Politik Bilimler Dergisi, 4(2), 172-201.

Güler B.S., ve Arıkan, E. (2021). Tüketicilerin bütünleşik pazarlama iletişimi ile reklam ve parasal satış promosyonlarının kullanılmasına yönelik algılarının marka denkliği üzerindeki etkileri. Elektronik Sosyal Bilimler Dergisi, 20(77), 217-239.

İpçioğlu, İ., ve Arpa, D. (2020). Marka değeri ile kurumsal itibar ilişkisinin incelenmesine yönelik bir araştırma. Alanya Akademik Bakış, 4(3), 821-841.

İrfanoğlu, M. (2021). Tüketmeme: neden bazı tüketiciler finansal güce sahipken, bilinçli bir şekilde marka kaçınması çerçevesinde tüketmeme eğilimi gösterirler? Doğuş Üniversitesi Dergisi, 22(2), 53-71.

Kahraman, M., ve Dağlı, S. (2019). Marka algısı, müşteri memnuniyeti ve marka tercihi ilişkisinin x ve y kuşağına göre incelenmesi. Uluslararası Ekonomi Işsletme ve Politika Dergisi, 3(2), 381-398.

Karataş A.Ö., ve Bekci, İ. (2017). Bulanık AHP yöntemi ile finansal marka değerleme modellerinin tespiti: bankacılık sektöründe bir uygulama. Muhasebe ve Finansman Dergisi, (75), 31-54.

Koçak, A., ve Bayraktar, A. (2019). Marka menșei tanıma doğruluğu kavramı ve mısır pazarındaki Türk markaları üzerine bir araştırma. Journal of Research ın Business, 4(2), 111-123.

Koçan, M., ve Gerekan, B. (2017). Faaliyet gider gürlerinin marka değeri üzerine etkisi: Brand Finance Turkey-100'de yer alan şirketlere yönelik bir araştırma. Muhasebe Bilim Dünyası Dergisi, 19(4), 884-914.

Meriç, K., ve Yüce, A. (2021). Marka bilgisi ve tüketici-marka ilginliğinin marka evangelizmine etkisinde dişa dönüklük ve deneyime açıklık kişilik özelliklerinin rolü. Pazarlama ve Pazarlama Araştırmaları Dergisi, 14(2), 359-388.

Müftüoğlu, M., ve Ünal, S . (2021). Tüketicilerin marka nefretinin marka misillemesi bağlamında incelenmesi. Journal of Business Innovation and Governance, 4(1), 42-56.

Nergiz, E., ve Çetindağ, F. (2019). Uluslararası pazarlamada markalaşmanın önemi: mavi jeans örneği. Middle Black Sea Journal of Communication Studies, 24-39.

Onan, G. (2017). Bankacılık sektöründe hizmet kalitesinin marka bağlılığı üzerine etkisi. Ordu Üniversitesi Sosyal Bilimler Enstitüsü Sosyal Bilimler Araştırmaları Dergisi, 7(3), 529-538. 
Öcel, Y. (2019). Türkiye'de marka ile ilgili yazılan doktora tezlerinin bibliyometrik incelenmesi. Uluslararası Batı Karadeniz Sosyal ve Beşeri Bilimler Dergisi, 3(1), 38-49.

Önder, C. (2019). Şirket ve bankaların marka değeri ile mali performansları üzerine bir araştırma. Bankacılık ve Sermaye Piyasası Araştırmaları Dergisi, 3(8), 22-36.

Özden, A. (2020). The relationship between consumers' tendency to forgive and their brand loyalty: a new strategy proposal. Süleyman Demirel Üniversitesi Vizyoner Dergisi, Cilt: 11 Say1: Ek, 134-149.

Özer, Ö. (2019). Arketipsel marka kişiliğinin tüketicinin satın alma niyeti üzerindeki etkisi. Ahi Evran Üniversitesi İktisadi ve İdari Bilimler Fakültesi Dergisi, 3(2), 85-107.

Özdemir, S., Kayhan, R., ve Aksoy Ö.İ.(2021). Pandemi (covid-19) döneminde kaynak güvenilirliği boyutlarının, elektronik ağızdan ağıza iletişimin ve marka imajı boyutlarının tüketici satın alma niyeti üzerindeki etkisi: instagram fenomenleri üzerine bir araştırma. Pazarlama ve Pazarlama Araştırmaları Dergisi, 14(1), 113-146.

Öztürk, A., ve Balyaş, B. (2021). Reklam müziğinin marka bilinirliği ve satın alma niyetine etkisi. Uluslararası Ekonomi İşletme ve Politika Dergisi, 5(1), 136-155.

Paksoy, H., Özbezek, B., ve Gül, M. (2020). Scale development study for determ1nıng the brand equity of academıcs. İktisadi İdari ve Siyasal Araştırmalar Dergisi, 5(11), 53-68.

Sargın, S., ve Leblebici K.L. (2020). Marka kişiliği ve benlik saygısı kavramlarının tüketici satın alma tarzları üzerindeki etkisi: üniversite öğrencileri üzerine bir uygulama. Erciyes Üniversitesi Sosyal Bilimler Enstitüsü Dergisi, (50), 23-57.

Sarıçiçek, R., Çokay Çopuroğlu, F., ve Korkmaz, İ. (2017). Brand identity and brand image of consumers in retro marketing context: a research on gaun academicians. Gaziantep University Journal of Social Sciences, 16(2), 345-358.

Soyaltın, T., ve Turkyılmaz, C. (2021). Retro müziğin tüketiciler üzerinde marka algısı yaratmadaki etkilerinin nöropazarlama çerçevesinde incelenmesi. Pressacademia Procedia, 13(1), 107-108.

Türk, Z. (2021). Tüketicilerin ağızdan ağıza pazarlama faaliyetlerinde marka sadakati ve markaya yönelik algılanan kalitenin etkisi üzerine bir araştırma. Çankırı Karatekin Üniversitesi İktisadi ve İdari Bilimler Fakültesi Dergisi, 11(1), 1-27.

Uğur, U., ve Sarığlu US. (2020). Kişilik özelliklerinin marka değiştirme davranış1 üzerine etkisi: bir araştırma. Uluslararası Yönetim İktisat ve İ̧sletme Dergisi, 16(1), 160170.

Yaprak, İ., ve Dursun, Y. (2018). Tüketicilerin kişilik özelliklerinin marka sadakati ile ilişsisi: kayseri'de yaşayan üniversite öğrencileri üzerinde bir uygulama. Gaziantep University Journal of Social Sciences, 17(2), 618-632.

Yavuzalp M.A., ve Aydın, A. (2021). Marka otantikliği ve marka sadakati arasında- 
ki ilişkide marka aşkının düzenleyici rolü. Pazarlama ve Pazarlama Araştırmaları Dergisi, 14(1), 83-112.

Yayman, F. (2021). Bankacılık hizmetlerinde marka algıları ve hizmet kalitesinin algılanan değer, müşteri tatmini ve bağl1lığına etkileri. Journal of Management Marketing and Logistics, 8(1), 34-52.

Yıldız, E., ve Günaydın, R. (2019). Marka aşkının öncülleri ve sonuçları: Doğu Karadeniz Bölgesi'nde bir uygulama. Optimum Ekonomi ve Yönetim Bilimleri Dergisi, 6(2), 323-338.

Yıldız, E., ve Koçan, M. (2019). Tüketici etnosentrizmi, algılanan kalite ve marka sadakatinin marka kişiliği üzerindeki etkisi: krem çikolata tüketicileri üzerine bir uygulama. Bingöl Üniversitesi Sosyal Bilimler Enstitüsü Dergisi, 9(17), 309-326.

Yıldız, E., ve Kırmızıbiber, A. (2020). Marka logolarının marka özgünlüğü üzerindeki etkileri. Ordu Üniversitesi Sosyal Bilimler Enstitüsü Sosyal Bilimler Araştırmaları Dergisi, 10(3), 749-761.

Yıldız, S., ve Avcı, İ. (2019). Tüketici temelli marka değerinin taklit markalı ürün algısı üzerindeki etkisi. Bingöl Üniversitesi Sosyal Bilimler Enstitüsü Dergisi, 9(17), 189214.

Y1lmazer, E., ve Nart, S. (2020). Erkek hazır giyim sektöründe tüketici temelli marka değerinin ölçülmesine yönelik bir araştırma. Balıkesir Üniversitesi İktisadi ve İdari Bilimler Fakültesi Dergisi, 1(1), 73-93.

Yüce, A., Samsa, Ç., ve Meriç, K. (2019). Effects of nostalgia proneness on consumer-based brand equity: a case study on the eastern express. Mehmet Akif Ersoy Üniversitesi İktisadi ve İdari Bilimler Fakültesi Dergisi, 6(1), 199-212. 


\section{EXTENDED ABSTRACT}

Businesses value brand and brand management operations in order to distinguish their products from those of competitors and to maintain the level of quality that they guarantee to customers. The brand, which can be a name, a sign, a symbol, a logo, or a color, has become an important part of marketing efforts for businesses looking to gain a foothold in the market and grow sales volume.

From this perspective, the purpose of this study is to conduct a literature analysis of papers that examine the ideas of brand and brand management, which have become increasingly relevant in recent years as a result of increased rivalry with international marketing. In this approach, studies on brand and brand management were thoroughly reviewed, with the goal of creating tools and assisting people affected.

The major body of this research is made up of 61 articles on the idea of branding or brand management in marketing that were published in DergiPark between 2013 and 2021. According to the findings of the literature study, research mostly focus on brand loyalty and brand value. Among the research on branding, only one study in the form of literature analysis was located, but because this study only covers doctorate theses, it was requested to fill the gap in the literature.

Finally, it was discovered that there are few research on brand performance, brand attitude, brand equity, brand love, brand evangelism, and brand retaliation in the relevant literature. In the globalizing market, the brand has become one of the most significant aspects of competition. In order to compete in the long run, businesses must establish well-known brands in the sale and promotion of their products, as well as do all it takes to maintain brand value.

When the literature on the subject is reviewed, it is seen that many articles focus on brand value and brand loyalty (Karataş \& Bekçi, 2017; Akgün \& Tekin, 2019; Önder, 2019; Aksoy, 2020; Doğanl1, 2021). Among other articles on brand, there are studies that touch on the subject of brand personality (Atıgan, 2019; Yıld1z \& Karabiber, 2020; Özhan \& Yüksel, 2020; Sargın \& Koçer, 2020).

Finally, it has been determined that subjects such as the archetypal brand and brand evangelism are rarely mentioned (Özer, 2019; Meriç \& Yüce, 2021).The goal of this research is to conduct a literature evaluation of papers linked to branding, which is an essential field of activity that organizations should pay attention to in order to compete sustainably. Document analysis was carried out in the study by respecting the originality of the articles while defining, evaluating, classifying, and interpreting the data.

The full count approach was used to identify the articles written on the brand in Dergi Park between 2013 and 2021 for the study. The following filtering was done on the papers published in Dergipark, which is a significant forum for scientific studies: The 
DergiPark search button was used to enter the brand word. In article filtering, the term "brand" was used. Business has been designated as a subject. English and Turkish were chosen as supported languages, as well as titles and keywords in the search fields; research articles were chosen as the type of article, and the years 2013 and after were chosen to analyze the most recent ones at the time of publishing. As a result of this method, 61 articles were examined.

As a result of the research, it has been determined that the majority of brand-related articles published within the scope of DergiPark focus on brand loyalty and brand value. Subjects such as brand evangelism, brand retribution, brand love, brand equity, brand avoidance, brand hatred, brand performance, and brand associations, on the other hand, are rarely covered. Another finding of the research is that studies with many authors are more common. Another conclusion is that most of the studies are published in national journals. Because there is only one study on the subject, comparing these results to other studies on the subject is challenging. The research, which took the form of a literature review (Öcel, 2019), looked at doctorate theses.

Aspects of the study are comparable to the findings of this literature evaluation. The fact that brand studies deal with brand value and the majority of them are quantitative research are similar elements. More discussion of themes like brand evangelism, brand hatred, and brand love in future studies could add to the literature. Again, comparisons and reviews of the literature can be found in publications published on venues other than DergiPark. The articles published in DergiPark between 2013 and 2021 were reviewed in this study; it is expected to contribute to the literature in terms of both the method utilized and the subjects investigated. 